\title{
Cutting Force Modelling with a Combined Influence of Tool Wear and Tool Geometry
}

Petr Kolar, Matej Sulitka, Petr Fojtů, Jiří Falta, Jaroslav Šindler

Research Center of Manufacturing Technology, Faculty of Mechanical Engineering, Czech Technical University in Prague. Horska 3, 12800 Prague. Czech Republic. E-mail: p.kolar@rcmt.cvut.cz

Modelling of cutting forces is important for understanding and simulation of the machining processes. This paper
presents cutting force modelling of data obtained from machining of C45 carbon steel with a coated carbide tool.
The model is based on a rather extensive measurement of 270 combinations of cutting tool geometry parameters
(rake angle, clearance angle and helix angle), tool wear (flank wear average value), chip thickness and cutting
velocity. The model with the friction and cutting component of the cutting force is presented and discussed. We
conducted an analysis of the identified model and found a relationship between the increase in tangential and
radial cutting forces and tool wear. We concluded that flank wear influences the cutting force acting on the worn
tool more significantly than cutting tool geometry. This is caused by changes in cutting edge geometry and the
resultant significant increase in the friction component of the cutting force as is shown using the identified model.

Keywords: Cutting Forces, Cutting Force Modelling, Flank Wear, Milling

\section{Acknowledgement}

This work has been funded by the Czech Ministry of Education, Youth and Sport within the grant No. LH12065. The support is gratefully acknowledged.

\section{References}

[1] MARTELLOTTI, M.E. (1941). An analysis of the milling process. In: Transactions of ASME, Vol. 63, pp. 677.

[2] MARTELLOTTI, M.E. (1945). An analysis of the milling process II. Down milling. In: Transactions of ASME, Vol. 67, pp. 233.

[3] KIENZLE, O. (1952). Die Bestimmung von Kräften und Leistungen an spanenden Werkzeugen und Werkzeugmaschinen. In: Zeitschrift des Vereins deutscher Ingenieure, pp. 657-662.

[4] SABBERWAL, A.J.P. (1962). Cutting forces in down milling. In: International Journal of Machine Tool Design and Research, Vol. 2, pp. 27-41.

[5] FU, H.J., DEVOR, R.E., KAPOOR, S.G. (1984). A mechanistic model for the prediction of the force system in face milling operations. In: Journal of Manufacturing Science and Engineering, Vol. 106, No. 1, pp. 81-88.

[6] SPIEWAK, S. (1995). An improved model of the chip thickness in milling. In: Annals of the CIRP, Vol. 44, No. 1, pp. 39-42.

[7] EHMANN, K.F., KAPOOR, S.G., DEVOR, R.E., LAZOGLU, I. (1997). Machining process modeling: a review. In: Transactions of ASME, Journal of Manufacturing Science and Engineering, Vol. 119, No. 4B, pp. 655-663.

[8] BUDAK, E., ALTINTAS, Y., ARMAREGO, E. (1996). Prediction of milling force coefficients from orthogonal cutting data. In: Journal of Manufacturing Science and Engineering, Vol. 118, No. 2, pp. 216-224.

[9] ALTINTAS, Y. (2000). Manufacturing automation: metal cutting mechanics, machine tool vibrations, and CNC design. Cambridge University Press, ISBN 0-521-65973-6.

[10] LEE, P., ALTINTAS, Y. (1996). Prediction of ball-end milling forces from orthogonal cutting data. In: International Journal of Machine Tools \& Manufacture, Vol. 36, No. 9, pp. 1059-1072.

[11] FENG, H.Y., SU, N. (2001). A mechanistic cutting force model for 3d ball-end milling. In: Journal of Manufacturing Science and Engineering, Vol. 123, No. 1, pp. 23-29.

[12] GAO, G., WU, B., ZHANG, D., LUO, M. (2013). Mechanistic identification of cutting force coefficients in bullnose milling process. In: Chinese Journal of Aeronautics, Vol. 26, No. 3, pp. 823-830.

[13] ALTINTAS, Y., LEE, P. (1996). A general mechanics and dynamics model for helical end mills. In: Annals of the CIRP, Vol. 45, No. 1, pp. 59-64.

[14] GRADISEK, J., KALVERAM, M. (2004). Mechanistic identification of specific force coefficients for a general end mill. In: International Journal of Machine Tools \& Manufacture, Vol. 44, No. 4, pp. 404-14.

[15] KAYMAKCI, M., KILIC, Z.M., ALTINTAS, Y. (2012). Unified cutting force model for turning, boring, drilling and milling operations. In: International Journal of Machine Tools \& Manufacture, Vol. 54-55, pp. 34-45. 
[16] ORABY, S.E., HAYHURST, D.R. (1991). Development of models for tool wear force relationships in metal cutting. In: International Journal of Mechanical Sciences, Vol. 33, No. 2, pp. 125-138.

[17] TEITENBERG, T.M., BAYOUMI, A.E., YUCESAN, G. (1992). Tool wear modeling through an analytic mechanistic model of milling processes. In: Wear, Vol. 154, No. 2, pp. 287-304.

[18] LIN, S.C., YANG, R.J. (1995). Force-based model for tool wear monitoring in face milling. In: International Journal of Machine Tools and Manufacture, Vol. 35, No. 9, pp. 1201-1211.

[19] LIN, S.C., LIN, R.J. (1996). Tool wear monitoring in face milling using force signals. In: Wear, Vol. 198, pp. 136142.

[20] LIN, M., LUCAS, H.C., SHMUELI, G. (2013). Too Big to Fail: Larger Samples and False Discoveries. In: Robert H. Smith School Research Paper, No. RHS 06-068, pp. 1-12. http://dx.doi.org/10.2139/ssrn.1336700

\section{Paper number: M2016102}

Copyright (C) 2016. Published by Manufacturing Technology. All rights reserved. 